\title{
Lithoglyphus naticoides (Pfeiffer) (Gastropoda: Prosobranchia): distribution in France, population dynamics and life cycle in the Saône river at Lyon (France)
}

\author{
J. Mouthon
}

Cemagref, DSA, 3 bis quai Chauveau, CP 220, F-69336 Lyon cedex 09, France. E-mail : mouthon@1yon.cemagref.fr

Lithoglyphus naticoides was observed for the first time in the north of France at the beginning of the 19th century, but since then this gastropod has only succeeded in colonising the eastern half of this country. A map showing its distribution in France is proposed. In the Saône river, L. naticoides is an annual species: spawning occurs from March to June and the juveniles that generally appear in May grow rapidly during the summer then spawn and disappear in the spring of the following year. Different observations suggest that increased water temperatures occurring in the context of global warming and potential/possible interspecific competition are the main reasons for the disappearance of L. naticoides in the Saône river at Lyon since November 2004.

Keywords: Lithoglyphus, life cycle, population dynamics, global warming, competition, Saône river

\section{Introduction}

Lithoglyphus naticoides (Fig. 1) originates from the western Black Sea. It emigrated to Western Europe (Germany and Netherlands) in the second part of the 19th century (Rémy 1924a, b, Bij de Vaate et al. 2002), by using the man-made canals interconnecting river basins and reached northeast France at the beginning of the 20th century (Cardot 1909, 1910). It inhabits the canals and lower reaches (potamon) of large rivers (Zhadin 1952, Gontya 1978, Mouthon 1999), though more rarely in lakes (Richnovsky \& Pinter in Frank 1990, Bij de Vaate \& Van Eerden 1990). This gastropod lives on stones or on the surface of sandy or muddy bottoms. In L. naticoides the sexes are separate (dioecious) but sexual dimorphism is not clearly apparent (Krause 1949, Zhadin 1952). The female lays its eggs, surrounded by a hemispherical capsule, on the shells of its congeners, sometimes completely covering the latter. According to Krause (1949) L. naticoides mainly ingests diatoms, algae debris and small organic particles. In spite of its presence in Western Europe for more than a century, little attention has been given to the life traits of this invader. The aim of this paper is to establish the distribution of this species in France, describe its life cycle and analyse the variations of its density in the Saône river at Lyon over a period of 9 years.

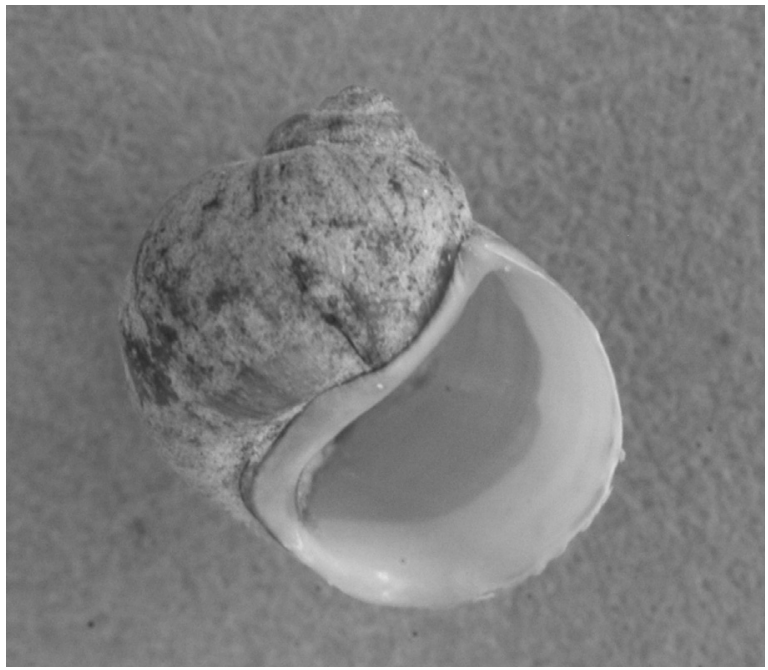

Fig. 1. Shell of Lithoglyphus naticoides, ventral view, height $6.5 \mathrm{~mm}$. Photograph by (C) D. Ricol and C. Helbling, 2007.

\section{Material and methods}

The distribution map of Lithoglyphus has been established on the basis of bibliographic data and several hundred quantitative and qualitative malacological surveys carried out by the author in French rivers, canals and lakes since 1977. 


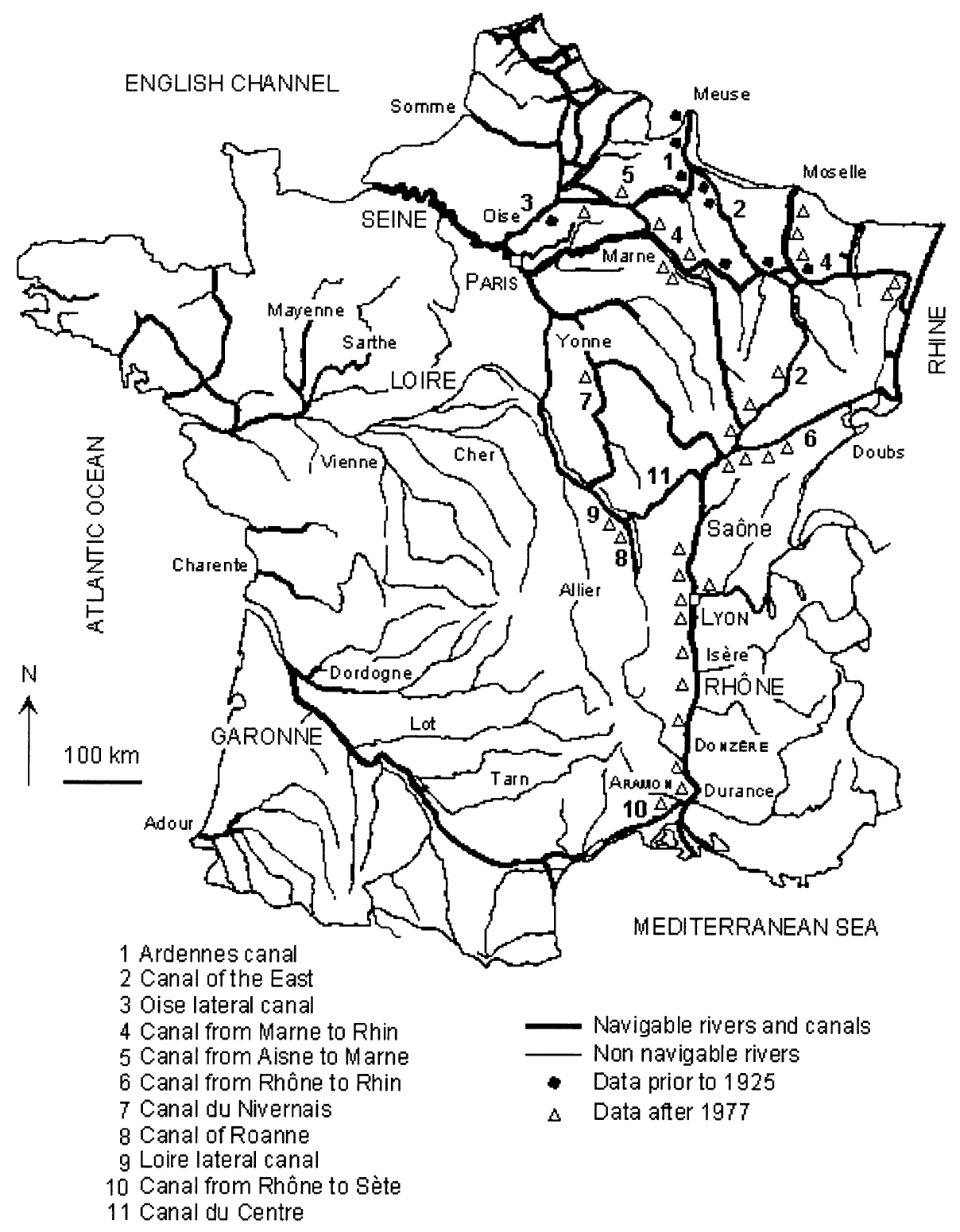

Fig. 2. Distribution of Lithoglyphus naticoides in France.

The mean daily temperatures of the Saône at lock of Couzon located about $10 \mathrm{~km}$ from the confluence with the Rhône, were obtained from automatic readings. These data were supplied by EDF (Electricité De France). Discharge rates at Macon, situated 78 km upstream from the confluence with the Rhône and downstream of the Saône's main tributaries the Doubs and Ognon rivers, were extracted from the HYDRO database (web site: http://hydro.rnde.tm.fr).
In the Saône river, molluscs were collected monthly (generally during the third week) from September 1996 to December 2005 upstream of the Ile Barbe, at the river's entry in the conurbation of Lyon (Fig. 2). At this point the river is approximately 150 meters wide, two thirds of this width being taken up by a navigable channel. The average slope of the Saône from the last lock to its confluence with the Rhône is $0.32 \mathrm{~m} \mathrm{~km}^{-1}$. The collection site, located on the right bank, was ap- 

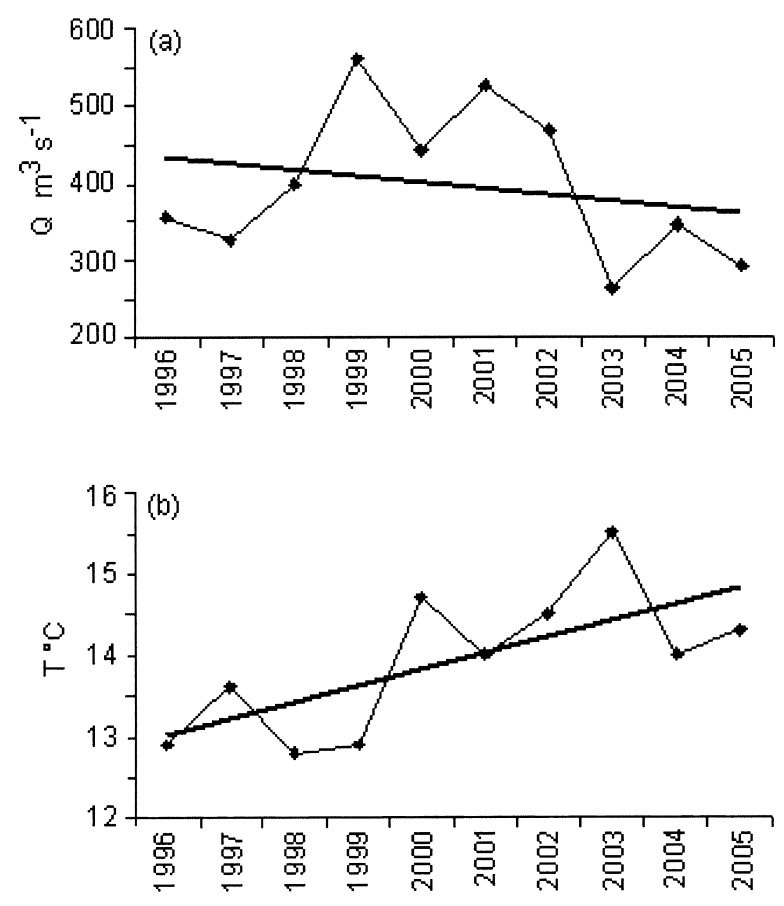

Fig. 3 (a) Mean annual daily discharge $(r=-0.24, p=0.50)$ and (b) mean annual daily water temperature $(\mathrm{r}=0.68, \mathrm{p}=0.03)$ at Macon from 1996 to 2005 . Trends are shown $(Y(t)=a t+b)$.

proximately 150 meters in length. From May to October, more than half its surface area was invaded by different species of macrophytes: Nuphar, Ceratophyllum, Potamogeton and filamentous algae. Sampling was carried out using a rectangular hand-net $(25 \times 18 \mathrm{~cm})$, sampling a total area of $0.25 \mathrm{~m}^{2}$ at every station. Four stations varying in depth from 0.50 to $1.5 \mathrm{~m}$ were sampled. Sampling was not possible during flood periods. These samples were kept separately and fixed on-site in $10 \%$ neutralised formaldehyde and then sieved at $500 \mu \mathrm{m}$ in the laboratory, where the molluscs were separated from the sediment and identified. Density was calculated based on the average of these 4 stations.

The shell height $(\mathrm{SH})$ i.e. the greatest length of individuals was measured with an eye piece micrometer at 25 x (gastropods with $\mathrm{SH}<6.0 \mathrm{~mm}$ ) or $12.5 \times$ (gastropods with $\mathrm{SH}>6.0 \mathrm{~mm}$ ) under a binocular microscope, and assigned to size classes of $0.5 \mathrm{~mm}$ width. The resulting histograms were analysed using Bhattacharya's (1967) graphical method available in the FiSAT software distributed by FAO-ICLARM (Gayanilo et al. 1996), which allows to separate each length-frequency distribution into Gaussian components. For each cohort, the mean size of the individuals, the number and the standard deviation were established.

\section{Results}

\section{Distribution in France}

Lithoglyphus naticoides was observed for the first time in France in the Ardennes canal (Cardot 1909) (Fig. 2). During the first quarter of the 20th century it reached the basins of the Seine (canal lateral to the Oise and from the Marne to the Rhine), the Meuse and then the Moselle (Rémy, 1924a, b). After this period, the extension of this species was no longer the subject of articles.

The surveys performed since 1977 show that its area of distribution has extended eastwards: it was present in the lower reaches of the Ill (Rhine basin) (Lafont et al. 1994), but above all towards the south where it was observed in the lower reaches of the Saône in 1983 (Tachet et al. 1988) then in the lower Rhône valley in 1984 (Cemagref 1985). The hydroelectric development schemes carried out by the Compagnie Nationale du Rhône during the second part of the 20th century have significantly favoured its colonisation and today this gastropod is present from upstream of Lyon to the Rhône delta. Although L. naticoides has not progressed westwards, it has nonetheless reached the Loire basin. Indeed, its presence has been observed in the canals of Roanne and lateral to the Loire at the intersection of which flows the Canal du Centre which links the Rhône and Loire basins. In France, L. naticoides mainly colonises canals, navigable waterways and rivers linked with canals (Aisne, Marne, Rhône, Saône, Doubs, Ill, etc.). Its distribution currently remains limited to the eastern half of the country.

\section{Population dynamics of Lithoglyphus in the Saône river at Lyon}

Environmental variables. - The Saône has a pluvialoceanic type hydrological regime (Pardé, 1925) with high flows in winter and spring and low flows in summer. The year of 2003 was characterised by a considerable water shortage with an mean annual flow of only $261 \mathrm{~m}^{3} \mathrm{~s}^{-1}$ (Fig. 3a). From 1996 to 2002 and in 2004 and 2005 the maximum water temperatures generally occurring in August ranged from $24.3^{\circ} \mathrm{C}$ in 1996 to $27.2^{\circ} \mathrm{C}$ in 2005 and the number of days during which temperatures were higher than $25^{\circ} \mathrm{C}$ ranged from 0 $(1996,1998,1999)$ to 17 (2001). In 2003, the temperature reached $29.5^{\circ} \mathrm{C}$ (August) and exceeded $25^{\circ} \mathrm{C}$ for 75 days. The mean temperature had increased by about $1.8{ }^{\circ} \mathrm{C}$ from 1996 to 2005 (Fig. 3b) (Mouthon \& Daufresne 2006). Regarding water quality, inter-annual variations in physico-chemical properties were weak 


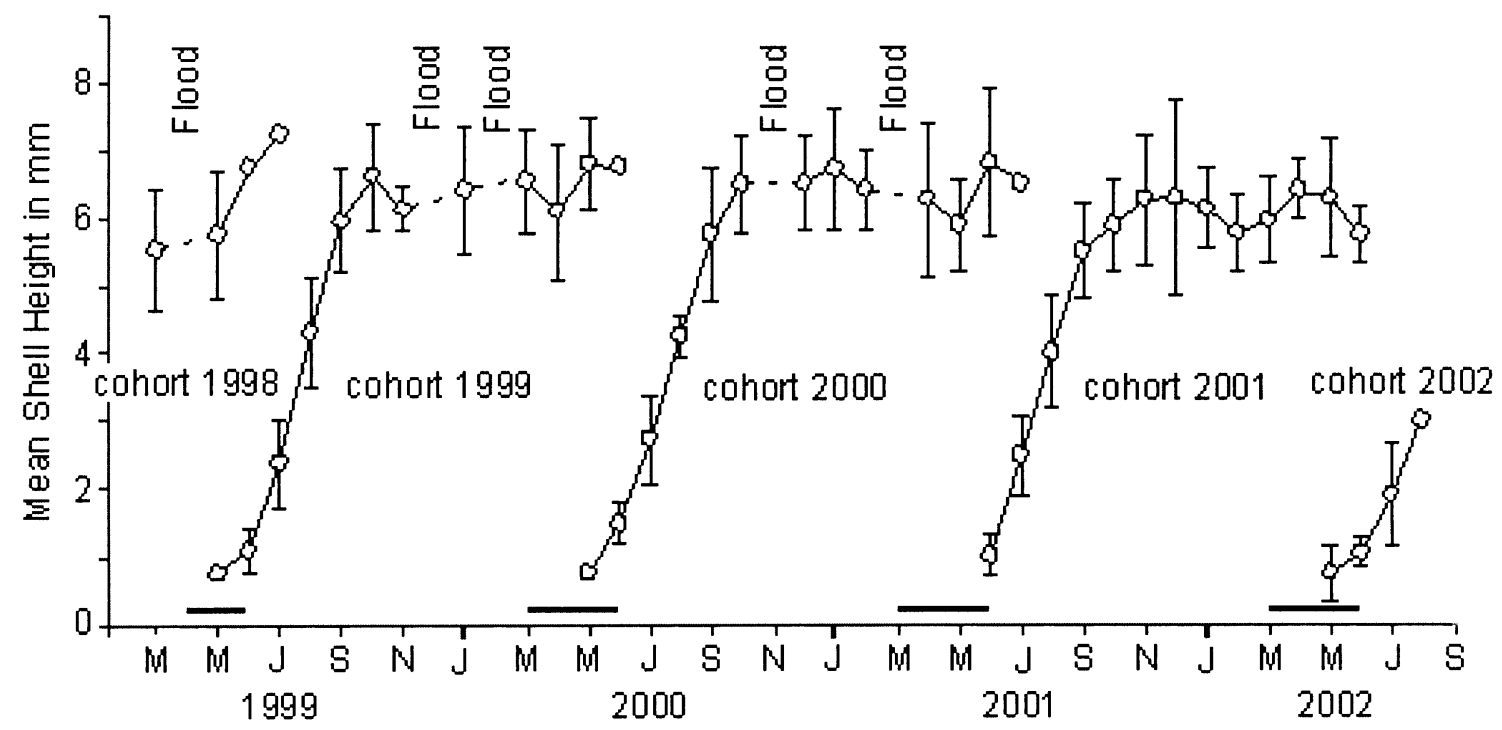

Fig. 4. Mean cohort shell lengths (open circles) in monthly samples of the Saône River Lithoglyphus naticoides population. Vertical bars are standard deviations. Dotted lines indicate the presumed changes in mean lengths. Solid bars above horizontal axis indicate spawning periods.

during the whole study period (for more details see Mouthon 2001, 2004 and data available at http://rdb.eaurmc.fr).

Life cycle and density variation of Lithoglyphus population. - The life cycle of the L. naticoides population of the Saône varied little during the period studied (Fig. 4). Adults that survive the winter spawn from March to June when they reach a shell height from 4 to $4.5 \mathrm{~mm}$, after which they disappear in June (2000 and 2002) or July (1999 and 2001). The new cohort appears in May and June (2001). The overlap of cohorts lasts only two months from May to June between the end of the spawning period and the appearance of newborn. The mean shell height of these newborn individuals was $0.75 \mathrm{~mm}$ in 1999, 2000 and 2002 and $1.02 \mathrm{~mm}$ in 2001 . They grew rapidly during the summer period and reached a size from 5.9 to $6.6 \mathrm{~mm}$ in October. This varied little during the winter. In 2002, the cohort born in May was only represented in August by two individuals. From 1999 to 2002, the mean shell height of Lithoglyphus decreased from 4.32 to $3 \mathrm{~mm}$ in August and from 5.95 to $5.5 \mathrm{~mm}$ at the end of summer from 1999 to 2001 (Table 1). The largest individual observed in the Saône river measured $8.0 \mathrm{~mm}$ (March 1999). L. naticoides only gives birth to one cohort per year and its lifespan varies from 13 to 15 months.
The annual density of Lithoglyphus increased progressively from 1997 to 2001 , rising from 34 to 1090 ind $\mathrm{m}^{-2}$ then decreased considerably in 2002 (267 ind $\mathrm{m}^{-2}$ ); from August the species was represented only sporadically by a few specimens $\left(\mathrm{N} \leq 5\right.$ ind $\left.\mathrm{m}^{-2}\right)$. In 2003, no significant production of newborn was observed, consequently its annual density only reached 16 ind $\mathrm{m}^{-2}$ and from November 2004 no individuals were collected (Fig. 5a). Peak density, which occurred every year in June, was maximal in 2001 (466 ind $\mathrm{m}^{-2}$ ).

Table 1. Life cycle data for Lithoglyphus naticoides. (SH= Shell Height)

\begin{tabular}{|c|c|c|c|c|c|}
\hline & 1999 & 2000 & 2001 & 2002 & 2003 \\
\hline Maximum $\mathrm{SH}(\mathrm{mm})$ & 8.33 & 8.16 & 7.83 & 7.66 & - \\
\hline Mean SH in August (mm) & 4.32 & 4.25 & 4.03 & 3.00 & - \\
\hline Mean SH in September (mm) & 5.95 & 5.75 & 5.50 & - & - \\
\hline Number of cohorts/year & 1 & 1 & 1 & 1 & 1 \\
\hline $\begin{array}{c}\text { Month at which the first cohort } \\
\text { appears }\end{array}$ & May & May & June & May & May \\
\hline Life-span (month) & 14 & 15 & 13 & $4 ?$ & $?$ \\
\hline $\begin{array}{l}\text { Month at which the total density } \\
\text { is maximum }\end{array}$ & June & June & June & June & June \\
\hline Total density (ind $\mathrm{m}^{-2}$ ) & 243 & 396 & 1090 & 267 & 16 \\
\hline
\end{tabular}




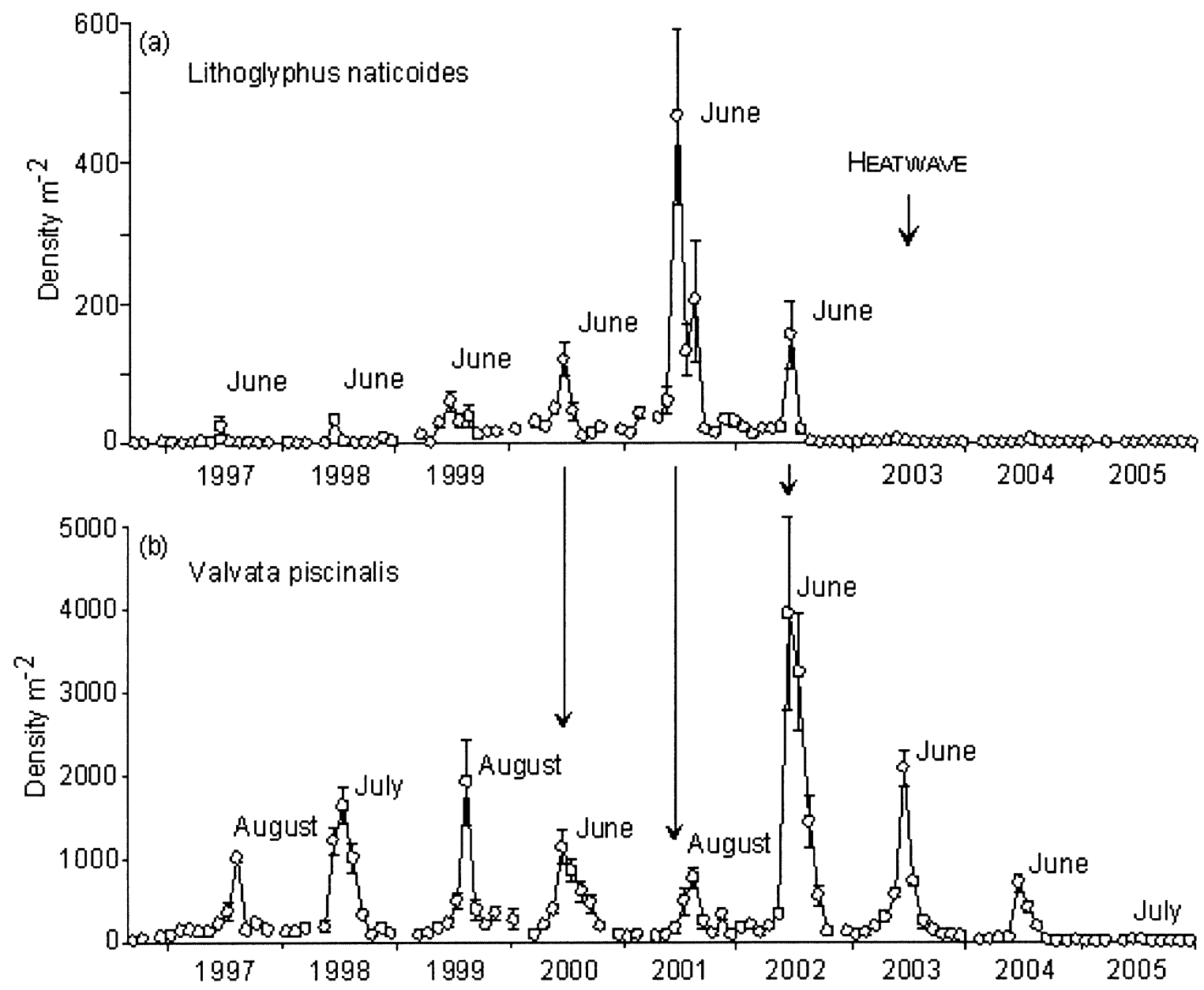

Fig. 5. Seasonal variations in the density populations of Lithoglyphus naticoides (a) and Valvata piscinalis (b), a potential competitor (see discussion), of the Saône River. Vertical bars are standard deviations.

\section{Discussion}

In the Ijsselmeer (Netherlands), the life cycle of L. naticoides is also annual (Bij de Vaate \& Van Eerden 1990). The cohort that appears in August grows little during the first year and most of its growth occurs during the following year, from April to October, after which the cohort disappears in December. Its life span is 16-17 months. Conversely, in the Saône river, the cohort that appeared in May-June grew rapidly during the summer of the same year then disappeared in June or July of the following year. Its life span is only 13-15 months. Short term colonisation then extinction of an L. naticoides population has been observed in the Ijsselmeer (Bij de Vaate \& Van Eerden 1990). The low maximal density of this species $\left(<100\right.$ ind $\left.\mathrm{m}^{-2}\right)$ and of the other gastropods present (Potamopyrgus antipodarum (Gray) and Valvata piscinalis (Müller)) led these authors to conclude that the unsuitability of this lake as a habitat must be the cause of the extinction of L. naticoides.

In the Saône river, the fall in density then disappearance of $L$. naticoides occurred following an increase of the average temperature by $1.6^{\circ} \mathrm{C}$ from 1999 to 2002 and by $2.6^{\circ} \mathrm{C}$ from 1999 to 2003 , whereas mean annual flows only started decreasing from 2003 (Fig 3) and following a substantial and sudden increase of its population (466 ind $\mathrm{m}^{-2}$ in June 2001). A similar phenomenon was observed in V. piscinalis (Fig 5) which disappeared after the 2003 heatwave whose conse- 
quences have been dramatic for mollusc communities (Mouthon \& Daufresne 2006, 2007).

Lithoglyphus generally spawn on the shells of their congeners. In the Saône river, they also use those of $V$. piscinalis for depositing their eggs. These two species therefore share, at least from March to June, the same habitat, implying the possibility of competitive interactions between each other. When L. naticoides reached its maximal annual density (1090 ind $\left.\mathrm{m}^{-2}\right)$ in 2001 , that of $V$. piscinalis was at its lowest level since 1997 (2499 ind $\mathrm{m}^{-2}$ ) and its peak density occurred two months later than the previous year (Fig. 5ab). On the other hand, in 2002 the peak density of the two species occurred in June, but while V. piscinalis reached its maximal annual density $\left(10.472\right.$ ind $\left.\mathrm{m}^{-2}\right)$ that of L. naticoides decreased heavily $\left(267 \mathrm{ind}^{-2}\right)$. In 2003 , the population of $V$. piscinalis still reached 4611 ind $\mathrm{m}^{-2}$ but that of $L$. naticoides was only represented by 16 ind $\mathrm{m}^{-2}$. Furthermore, the growth of Lithoglyphus decreased constantly from 1999 to 2002, with the average size of individuals falling from 4.32 at the end of August to $3.0 \mathrm{~mm}$, whereas that of Valvata increased from 2.24 to $2.5 \mathrm{~mm}$ and even reached $3.58 \mathrm{~mm}$ in 2003 (Mouthon \& Daufresne, 2007). These observations suggest that the increase in temperature of the waters occurring in the context of global warming and potential/possible interspecific competition are the main reasons for the fall in density then disappearance of L. naticoides in the Saône river at Lyon from November 2004.

The colonisation of the whole of metropolitan France required slightly less than thirty years for Dreissena polymorpha (Pallas) but only twenty for Corbicula fluminea (Müller) (Mouthon 2000). On the contrary, it has taken L. naticoides almost the entire twentieth century to colonise only the eastern half of the country although its rapid propagation had been envisaged (Rémy 1924b, Germain 1931). Also its southernmost extension is solely due to the hydroelectric development schemes carried out on the Rhône. According to the "tens rule" only 1 in 10 of established species become a pest (Holdgate 1986, Williamson \& Brown 1986, Williamson \& Fitter 1996). The biological traits of $L$. naticoides are a relatively short spawning period, the production of a single cohort per year, the absence of natural mechanisms for rapid dispersal (see Ricciardi \& Rasmussen 1998) and possible interspecific competition with native gastropods, all of which undoubtedly explain the very slow extension of this invasive species. Additional studies comparing the population dynamics of L. naticoides with this of $V$. piscinalis are required to identify the relations between these two species.

\section{Acknowledgements}

We thank A. Poirel (EDF, Grenoble) for water temperature data, P. Breil (Cemagref, Lyon) for discharge data, M. Daufresne (Cemagref) for his assistance, D. Ricol and C. Helbling for the photograph of Lithoglyphus.

\section{References}

Bhattacharya C.G. 1967. - A simple method of resolution of a distribution into Gaussian components. Biometrics, 23: 115-135.

Bij de Vaate A. \& Van Eerden A. 1990.- Short term colonization and subsequent extinction of a population of Lithoglyphus naticoides (Pfeiffer) (Gastropoda, Prosobranchia, Hydrobiidae) in the Ijsselmeer, The Netherlands. Basteria, 54, 217-226.

Bij de Vaate A., Jazdzewski K., Ketelaars H.A.M., Gollasch S. \& Van der Velde G. 2002. - Geographical patterns in range extension of Ponto-Caspian macroinvertebrate species in Europe. Can. J. Fish. Aquat. Sci., 59, 1159-1174.

Cardot H. 1909. - Faune malacologique du département des Ardennes. Bull. Soc. Hist. Nat. Ardennes, 16, 49-104.

Cardot H. 1910. - Sur la présence de Lithoglyphus naticoides Fér. Dans les eaux du Nord-Est de la France. J. de Conch., 43, 131-137.

Cemagref 1985. - Etat biologique du Rhône. Site de St Etienne-desSorts. Rapport, Groupement de Lyon, 69 pp.

Frank C. 1990. - Ein Lebendnachweis von Lithoglyphus naticoides (C. Pfeiffer 1828) in der österreichisch-bayrischen Donau (Gastropoda: Prosobranchia: Hydrobiidae). Arch. Hydrobiol. Suppl., 84, 98-98.

Gayanilo F.C., Sparre P. \& Pauly D. 1996. - FAO-ICLARM stock assessment tools. Food and Agriculture Organization of the United Nations, Rome, Computed information series 8, 1-126.

Germain L. 1931. - Mollusques terrestres et fluviatiles. In : Faune de France, Lechevalier (ed.), Paris 21-22, 897 pp.

Gontya F.A. 1978.- Some results of the studies of mollusks from waterbodies of the Dniester drainage. Malac. Rev., 11, 88.

Holdgate M.W. 1986. - Summary and conclusions: characteristics and consequences of biological invasions. Phil. Trans. r. Soc., Lond., B 314, 733-742.

Krause von H. 1949. - Untersuchungen zur Anatomie und Ökologie von Lithoglyphus naticoides (C. Pfeiffer). Arch. Moll., 78, 103-148.

Lafont M., Faessel B., Mouthon J. \& Roger M. C. 1994. - Etude préalable à la mise en place d'une surveillance de la pollution toxique des bassins de l'Ill et de la Thur à l'aide des invertébrés benthiques. Agence de l'Eau Rhin-Meuse/Cemagref, 110 pp. + annexes.

Mouthon J. 1999. - Longitudinal organisation of the mollusc species in a theoretical French river. Hydrobiologia, 390, 117-128.

Mouthon J. 2000. - Répartition du genre Corbicula Megerle von Mühlfeld (Bivalvia : Corbiculidae) en France à l'aube du $\mathrm{XXI}^{c}$ siècle. Hydroécol. Appl., 12, 135-146.

Mouthon J. 2001. - Life cycle and population dynamics of the Asiatic clam Corbicula fluminea (Bivalvia: Corbiculidae) in the Saône River at Lyon (France). Hydrobiologia , 452, 109-119.

Mouthon J. 2004. - Life cycle of Musculium lacustre (Bivalvia : Sphaeriidae) in Saône river at Lyon (France): a curious (reproductive) strategy. Ann. Limnol. - Int. J. Lim., 40, 279-284.

Mouthon J. \& Daufresne M. 2006. - Effects of 2003 heatwave and climatic warming on mollusc communities of the Saône : a large lowland river and its two main tributaries (France). Global Change Biology, 11, 1-9.

Mouthon J. \& Daufresne M. 2007. - Effects of 2003 heatwave and climatic warming on the population dynamics and life cycle of Valvata piscinalis (Müller) (Gastropoda: Prosobranchia) in the Saône, a large lowland river (France). Hydrobiologia, in press. 
Pardé M. 1925. - Le régime du Rhône. Etude hydrologique, Lyon (études et travaux de l'I.E.R) Thèse Lettres, Grenoble, vol. 1 et 2 : $883+440 \mathrm{pp}$.

Remy P. 1924a. - Note sur la répartition géographique de Lithoglyphus naticoides De Férussac (Gastrop. Prosobr.). Ann. Biol. Lac., 13, 83-91.

Remy P. 1924b. - Géonémie du genre Lithoglyphus (Gastrop. Prosobr.) - Migration vers l'ouest de l'Europe d'une espèce pontique, Lithoglyphus naticoides De Férussac. Arch. Zool. exp. gén., 62, 4-20.
Ricciardi A. \& Rasmussen J. B. 1998. - Predicting the identity and impact of future biological invaders: a priority for aquatic resource management. Can. Fish. Aquat. Sci., 55, 1759-1765.

Tachet H., Gaschignard-Fossati O., Cellot B. \& Berly A. 1988. - Le macrobenthos de la Saône. Ann. Limnol. - Int. J. Lim., 24, 83-100.

Williamson M.H. \& Brown K.C. 1986. - The analysis and modelling of British invasions. Phil. Trans. r. Soc., Lond., B 314, 505-522.

Williamson M.H. \& Fitter A. 1996. - The varying success of invaders. Ecology, 77, 1661-1666.

Zhadin V.I. 1952. - Mollusks of freshwater and brackish waters of the U.S.S.R. 